\title{
Effect of Kinesiotaping on Quality of Life of Knee Osteoarthritis Patients
}

\author{
Aditya Paramitha, Rahmi Isma
}

Department of Physical Medicine and Rehabilitation, Faculty of Medicine Diponegoro University, Semarang, Indonesia

\begin{abstract}
Introduction: Knee osteoarthritis (OA) causes pain which limits functional activity and quality of life. Quadriceps femoris muscle strengthening with weight-pulley system is effective in improving functional activity. Kinesiotaping is known in reducing pain thus improving activity and quality of life. This study was to determine the effect of kinesiotaping in addition to weight-pulley system exercise on quality of life in grade II and III knee OA patients.

Methods: Participants were randomly assigned to intervention group $(n=13)$ and control group $(n=14)$. All participants were treated with weight-pulley system exercise for nine sessions meanwhile participants in intervention group received additional kinesiotaping. Pre- and post-intervention quality of life were evaluated using Medical Outcome Study Short Form-36 (SF-36).

Results: There were differences in total score of SF-36, bodily pain, general health, vitality, and role emotional between intervention and control group; $(90.53 \pm 8.23,76.98 \pm 11.88 ; \mathrm{p}=0.002),(83.75 \pm 16.86$, $67.31 \pm 17.3 ; p=0.022),(88.57 \pm 10.27,72.69 \pm 12.18 ; p=<0.001),(93.93 \pm 7.64,80.77 \pm 10.18 ; p=0.002)$ and $(92.86 \pm 14.18,74.37 \pm 24.17 ; \mathrm{p}=0.027)$, respectively.

Conclusion: Application of kinesiotaping in addition to weight-pulley system exercise improved quality of, particularly in bodily pain, general health, vitality and role emotional in grade II and III knee OA patients.
\end{abstract}

Keywords: Exercise, kinesiotaping, knee osteoarthritis, SF-36. 


\section{ABSTRAK}

Pendahuluan: Osteoarthritis lutut (OA) menyebabkan nyeri yang membatasi aktivitas fungsional dan menurunkan kualitas hidup pasien. Penguatan otot quadriceps femoris menggunakan sistem weightpulley efektif dalam meningkatkan aktivitas fungsional pada pasien OA lutut. Kinesiotaping dikenal dapat menurunkan nyeri sehingga meningkatkan aktivitas dan kualitas hidup pasien. Penelitian ini bertujuan untuk mengetahui pengaruh penambahan kinesiotaping pada latihan sistem weight-pulley terhadap kualitas hidup pasien OA lutut derajat II dan III.

Metode: Peserta secara acak dibagi menjadi kelompok intervensi $(n=13)$ dan kelompok kontrol $(n=14)$. Semua peserta diperlakukan dengan latihan sistem weight-pulley selama sembilan sesi sementara peserta dalam kelompok intervensi menerima penambahan kinesiotaping. Kualitas hidup sebelum dan sesudah intervensi dievaluasi dengan menggunakan Medical Outcome Study Short Form-36 (SF-36).

Hasil: Nilai total SF-36, subskala nyeri tubuh, kesehatan umum, vitalitas, dan peran emosional antara kelompok intervensi dan kontrol, yaitu $(90.53 \pm 8.23$ dibandingkan $76.98 \pm 11.88, \mathrm{p}=0.002),(83.75 \pm 16.86$ dibandingkan $67.31 \pm 17.39, \mathrm{p}=0.022),(88.57 \pm 10.27$ dibandingkan $72.69 \pm 12.18, \mathrm{p}=<0.001),(93.93 \pm 7.64$ dibandingkan $80.77 \pm 10.18, \mathrm{p}=0.002)$ dan $(92.86 \pm 14.18$ dibandingkan $74.37 \pm 24.17, \mathrm{p}=0.027)$.

Kesimpulan: Kinesiotaping dikombinasi dengan latihan weight-pulley meningkatkan kualitas hidup, terutama dalam perbaikan nyeri, kesehatan umum, vitalitas, dan peran emosional pada pasien OA lutut derajat II dan III.

Kata Kunci: Kinesiotaping, latihan, osteoarthritis lutut, SF-36.

\section{Correspondent Detail:}

\section{Aditya Paramitha}

Email: adityaparamitha@gmail.com

Faculty of Medicine Diponegoro University, Dr. Kariadi General Hospital, Semarang, Indonesia

\section{INTRODUCTION}

Osteoarthritis (OA) is a progressive non-erosive, non-inflammatory disease in the joints which increases complications in the cartilage joints and the formation of new bone on the surface and edges of the joints. ${ }^{1} \mathrm{Knee} \mathrm{OA}$ is the overall most common type of arthritis., ${ }^{2,3}$ Prevalence of knee $\mathrm{OA}$ in Indonesia is up to $15,5 \%$ for men and $12,7 \%$ for woman. ${ }^{4}$ Meanwhile, in Clinic of Rehabilitation Medicine Dr. Kariadi General Hospital Semarang there were 63 visits of knee OA patients on August 2019. Knee OA has caused burden of disease, not only due to its chronicity and progressivity but also pain and productivity, that interferes patients' quality of life..$^{2,3,5}$

Pain is the main symptom of knee OA which limits function, participation and quality of life, hence improvement of pain is important in the management of knee OA. If pain is decreased, then it may improve quality of life. ${ }^{6}$ 
There are some effective programs to decrease pain, such as to decrease mechanical loading on knee, as well to strengthen quadriceps femoris muscle. ${ }^{7}$ Knee OA patients usually have weak quadriceps femoris muscle whereas quadriceps femoris muscle acts to stabilize and protect knee joint, moreover decrease joint load that causes pain. ${ }^{7,8}$ Thus, in the management of knee OA, strengthening of quadriceps femoris muscle has an essential role. Good quadriceps femoris muscle strength will decrease joint load and furthermore decrease pain in patients of knee OA. ${ }^{8,9}$

One of the programs of choice to strengthen quadriceps femoris muscle is weight-pulley system exercise. ${ }^{10}$ Weight-pulley system exercise is a dynamic muscle strengthening exercise with muscle contraction using a constant resistance/load and changes in muscle length (isotonic) during movement. ${ }^{10}$ Weightpulley system (ENTree brand) uses resistance with a pulley system so that the force can be adjusted through the direction of the rope, equipped with a bench to sit, ankle slings and a load of $0.5-24 \mathrm{~kg} .{ }^{11}$

In order to reduce pain, at the same time to improve quadriceps femoris muscle strength, kinesiotaping has been widely considered to be effective. ${ }^{12}$ Kinesiotaping is a method of therapy by applying an elastic tape on the skin. ${ }^{13}$ The kinesiotaping method was developed by Dr. Kenzo Kase from Japan in the 1970s with a view to reducing pain and improving soft tissue healing. Kinesiotaping has the characteristics of being stretchable longitudinally up to 120 $140 \%$ from its original length and can shrink back to its original length. ${ }^{14}$ Kinesiotaping is considered to decrease pain by stimulating sensory receptors of the skin which associated to the pain gate control theory, leading to pain alleviation. ${ }^{15}$ The elastic nature and pull of kinesiotaping may improve blood flow and influence directly pain perception. ${ }^{16}$ Since pain is the main contributor of functional limitations and disability in OA patients which lead to poor quality of life, it is hypothesized that the improvement of pain perception will increase patients' quality of life. ${ }^{6,16}$ Application of kinesiotaping from origo to insertion of a muscle may facilitate muscle performance and increase motor unit recruitment which is associated with the improvement of muscle strength. It is assumed that the improvement of quadriceps femoris muscle strength not only will decrease joint force that cause pain, but also may influence stability and mobility needed by the patients to participate and function, hence, obtaining a better quality of life. ${ }^{14,17}$

Pain is the main precursor of function limitation and disability in knee OA patients which reduces patients' productivity and quality of life..$^{5,7}$ Medical Outcome Study Short Form Health Survey (SF-36) is one of the most common instruments that has been widely used to assess knee OA patients' quality of life. ${ }^{18} \mathrm{SF}$ 36 consists of eight comprehensive subscales such as physical functioning, role physical, mental health, social functioning, bodily pain, general health, vitality and role emotional. ${ }^{19}$ The objective of this study was to determine the effect of kinesiotaping in addition to weight-pulley system exercise on quality of life assessed with SF-36 in grade II and III knee OA patients. 


\section{METHOD}

This reasearch was conducted in Murai Installation Dr. Kariadi General Hospital Semarang on April 2019. The design of this research is simple randomized controlled pre and post experimental design. Participants were recruited from outpatient Clinic of Rehabilitation Medicine Dr. Kariadi General Hospital with following inclusion criteria: age 40-65 years old, normal vital sign, clinically knee osteoarthritis based on American College of Rheumatology (ACR) criteria, radiography imaging showed grade II-III knee osteoarthritis based on Kellgreen and Lawrence criteria, knee pain at least at one knee with Numeric Pain Rating Scale (NPRS) 6-8 for more than 4 weeks, subject is able to climb and go down stairs without ambulation aid, Mini Mental State Examination (MMSE) score is normal $\geq 24$, Hamilton Rating Scale for Anxiety (HARS) score is normal $<14$, Self Efficacy for Exercise (SEE) score is normal (60-90), cooperative and be willing to follow the research protocol by signing informed consent.

The exclusion criteria was as following, from anamnesis: subjects who have acute inflammation, contracture, or surgery at knee region, experience intolerable pain during exercise, low back pain, history of trauma at knee, pregnant, muscle weakness as genetic disorder, history of heart disease, receive any physical modality and exercise aside from the research program at least one week before treatment, receive any application of kinesio taping at knee region at least one week before treatment, receive other treatment e.g.: analgetic, spasmolitic, or wear splint; from physical examination: body mass index (BMI) $>$ 30 , flat foot at the ipsilateral leg, knee instability (varus/valgus test positive); from radiology imaging: knee fracture, another rheumatic disease at knee, allergic, skin infection, wound, sign of deep vein thrombosis at the site that will be treated with kinesio taping, pain that is increased with weight-pulley system exercise.

Weight-pulley system exercise was performed with the EN-Tree tool. Subjects sit on an ENTree chair with a back-leaning position, hip and knee joints forming an angle of $90^{\circ}$, EN-Tree cufflinks were connected to the load attached to the lower limbs of the subjects distally. Exercise was imposed in this study following general guidelines as developed by American Geriatrics Society for people with OA pain. Before the exercise was started, we determined 1 repetion maximum (1RM) of the subjects and we gave load $40 \%$ of 1 RM. Subjects extended the knee to position $0^{\circ}$ with 10 repetitions of 3 sets and rested for 30 seconds between sets, the load is increased by $10 \%$ every week (Figure 2).$^{20}$ We used a standard width of $5 \mathrm{~cm}$ for the application of kinesiotaping in this research as developed by Kase. We applied kinesiotaping to (1) rectus femoris muscle, applied Y type, 10 $\mathrm{cm}$ below the anterior spinal iliaca spine to the inferior patella side and, (2) vastus medialis, type $\mathrm{Y}$ applied, $10 \mathrm{~cm}$ below the intertrochanter line to be connected to the medial patella with each pull by $40 \%$ (Figure 3). Kinesiotaping is applied for 3-5 days followed by a rest period without taping for 24 hours, in a period of 3 weeks. Kinesiotaping was applied at least 30 minutes before exercise. ${ }^{14}$ 


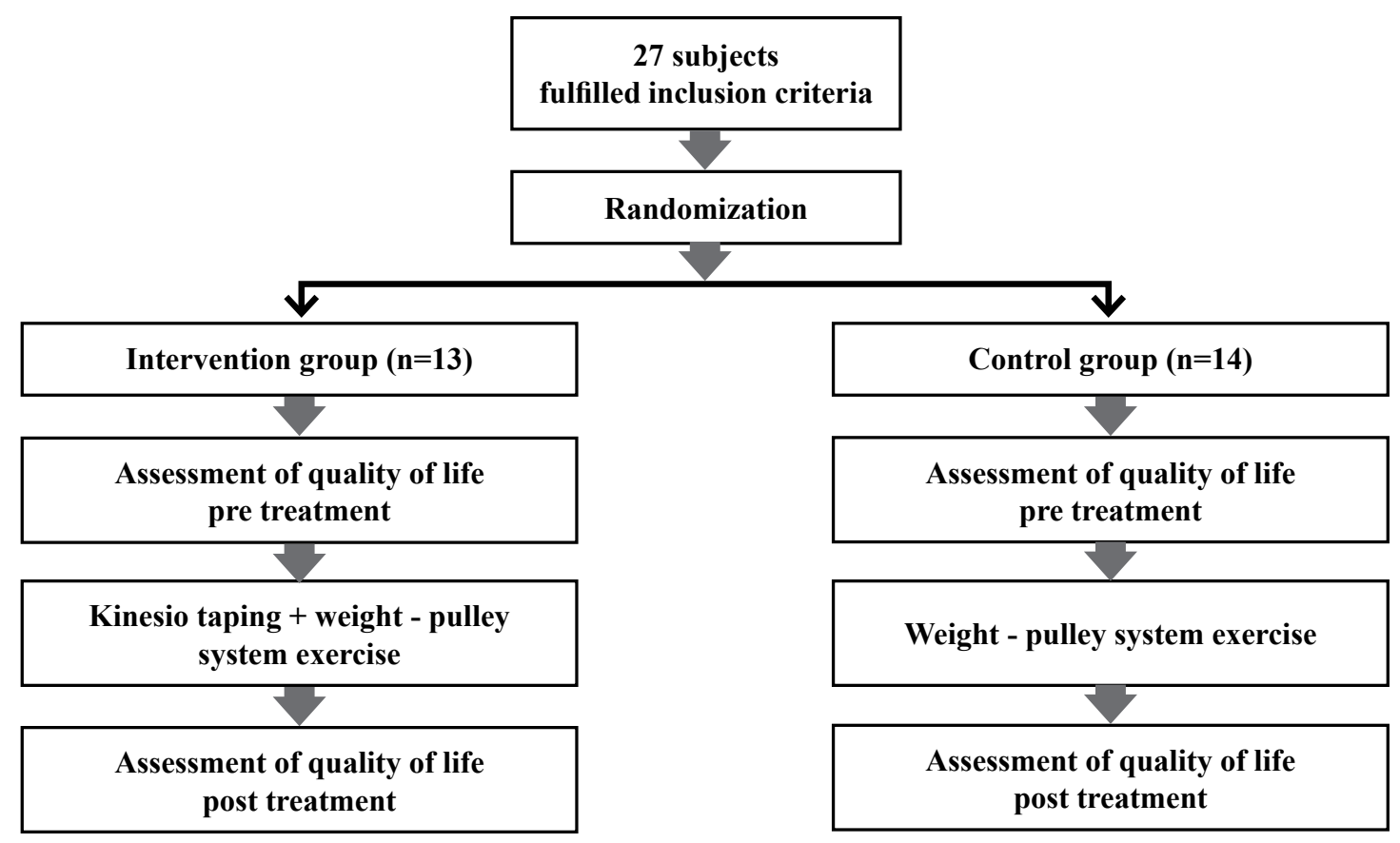

Figure 1. Flowchart of the research

Data was collected in data collection sheets and coded, tabulated and entered into a computer. We analyzed data including descriptive analysis and hypothesis testing. Before testing the hypothesis, the normality of the distribution was performed with Shapiro Wilk test. If the data was normally distributed then a hypothesis test would be performed with an independent $t$ test. If the data was not normally distributed then the Mann Whitney test would be performed. All of the data was processed with $\operatorname{SPSS}{ }^{\circledR}$ software. Significance in this study was obtained if $p$ values $<0.05$ with a $95 \%$ confidence interval.

\section{RESULTS}

Twenty seven subjects were randomly assigned into two groups (intervention group $n=13$, control group $n=14)$. Subjects in intervention group were treated with kinesiotaping for 3-5 days with washout period for 24 hours, for 3 weeks in addition to weight-pulley exercise using EN-Tree for 3 times per week (Monday, Wednesday and Friday) for 3 weeks with total 9 sessions. Meanwhile subjects in control group were only treated with weight-pulley system exercise using EN-Tree for 3 times per week (Monday, Wednesday and Friday) for 3 weeks with total 9 sessions. Before and after weight-pulley system exercise, subjects received warming-up and cooling down session by stretching extensor and flexor muscle group of the knee for 3-6 seconds. We assessed subjects' quality of life pre- and posttreatment using SF-36 questionnaire.

Characteristics of the subjects in this study were depicted in Table 1. There were no significant differences for the baseline characteristics before the treatment between intervention and control groups for age $(p=0.183)$, sex $(p=0.481)$, BMI $(p=0.147)$, OA grade $(p=0.165)$, NPRS $(p=0.853)$, nutritional intake $(\mathrm{p}=0.078)$, activity level $(p=0.192)$, MMSE $(p=0.068)$, HARS $(p=0.115)$, $\operatorname{SEE}(p=0.114))$, pain onset $(p=0.540)$. 
Table 1. Baseline characteristic

\begin{tabular}{|c|c|c|c|}
\hline \multirow{2}{*}{ Variable } & \multicolumn{2}{|c|}{ Group } & \multirow{2}{*}{$\mathbf{p}$} \\
\hline & Intervention $(n=13)$ & Control $(n=14)$ & \\
\hline Age & $64(41-65)$ & $59(44-65)$ & $0,183^{*}$ \\
\hline \multicolumn{4}{|l|}{ Gender } \\
\hline Male & $0(0 \%)$ & $1(7,7 \%)$ & $0,481^{\dagger}$ \\
\hline Female & $14(100 \%)$ & $12(92,3 \%)$ & \\
\hline BMI & $25,32 \pm 2,52$ & $23,53 \pm 3,60$ & $0,147^{\star}$ \\
\hline \multicolumn{4}{|l|}{ OA Grade } \\
\hline 2 & $9(64,3 \%)$ & $12(92,3 \%)$ & $0,165^{\dagger}$ \\
\hline 3 & $5(35,7 \%)$ & $1(7,7 \%)$ & \\
\hline NPRS & $6,5(6-8)$ & $7(6-8)$ & $0,853^{*}$ \\
\hline \multicolumn{4}{|l|}{ Nutrition intake } \\
\hline More carbohydrates & $8(57,1 \%)$ & $12(92,3 \%)$ & $0,078^{\dagger}$ \\
\hline More fiber & $4(28,6 \%)$ & $0(0 \%)$ & \\
\hline More protein & $2(14,3 \%)$ & $1(7,7 \%)$ & \\
\hline \multicolumn{4}{|l|}{ Activity } \\
\hline Mostly walking & $10(71,4 \%)$ & $6(46,2 \%)$ & $0,192^{\dagger}$ \\
\hline Mostly standing & $2(14,3 \%)$ & $1(7,7 \%)$ & \\
\hline Mostly sitting & $2(14,3 \%)$ & $6(46,2 \%)$ & \\
\hline MMSE & $28,64 \pm 1,22$ & $27,69 \pm 1,38$ & $0,068^{\ddagger}$ \\
\hline HARS & $2(2-6)$ & $3(2-6)$ & $0,115^{*}$ \\
\hline SEE & $91,71 \pm 3,95$ & $89,46 \pm 3,10$ & 0,114 \\
\hline Onset of pain & $1,5(0,25-5)$ & $3(0,02-25)$ & $0,540^{*}$ \\
\hline
\end{tabular}

${ }^{*}$ Mann Whitney; ${ }^{\dagger}$ Chi square; ${ }^{\ddagger}$ Independent t

We assessed subjects' quality of life using SF-36 and comparing each of its subscales pre- and posttreatment. In table 2, the mean total score of SF36 at the beginning of the study (pre-treatment) in the treatment group was $70.10 \pm 18.94$ and in the control group was $57.90 \pm 16.84$. However, from the independent t-test there was no significant difference in total score of SF-36 between the two groups. There were also no significant difference at the beginning of the study with Mann-Whitney test for each subscales: physical functioning, role physical, mental health, social functioning, bodily pain, general health, vitality and role emotional.

After 9 sessions of treatment (post-treatment), we reassessed patients' quality of life. The results of SF-36 subscales varied between two groups. Quality of life of the subjects both in intervention and control groups were improving at every subscale. However, from Mann-Whitney 
test, we obtained that there were no statistically significant difference for subscales physical functioning, role physical, mental health and social functioning between two groups at the end of the research with $p=0.052 ; p=0.159 ; p=0.091$; and $\mathrm{p}=0.065$ respectively (table 2 ). Meanwhile, the improvement of the quality of life was significantly better for the intervention group compared to control group for subscales bodily pain, general health, vitality and role emotional, with $\mathrm{p}=0.022 ; \mathrm{p}=<0.001 ; \mathrm{p}=0.002 ;$ and $\mathrm{p}=0.027$ respectively (table 2 ).

Table 2. Comparison of quality of life between intervention and control group

\begin{tabular}{|c|c|c|c|}
\hline \multirow{2}{*}{ Quality of life } & \multicolumn{2}{|c|}{ Group } & \multirow{2}{*}{$\mathrm{p}$} \\
\hline & Intervention $(\mathrm{n}=13)$ & Control $(n=14)$ & \\
\hline \multicolumn{4}{|l|}{ Physical functioning } \\
\hline -Pre & $65(25-95)$ & $35(25-70)$ & $0,080^{*}$ \\
\hline -Post & $95(80-100)$ & $60(60-100)$ & $0,052^{*}$ \\
\hline \multicolumn{4}{|l|}{ Role physical } \\
\hline -Pre & $100(0-100)$ & $25(0-100)$ & $0,131^{*}$ \\
\hline -Post & $100(50-100)$ & $50(25-100)$ & $0,159^{*}$ \\
\hline \multicolumn{4}{|l|}{ Mental health } \\
\hline -Pre & $84(68-100)$ & $84(64-100)$ & $1,000^{*}$ \\
\hline -Post & $100(88-100)$ & $88(88-100)$ & $0,091^{*}$ \\
\hline \multicolumn{4}{|l|}{ Social functioning } \\
\hline -Pre & $75(62,5-100)$ & $50(25-100)$ & $0,182^{*}$ \\
\hline -Post & $100(75-100)$ & $87,5(50-100)$ & $0,065^{*}$ \\
\hline \multicolumn{4}{|l|}{ Bodily pain } \\
\hline -Pre & $51,25(35-100)$ & $45(22,5-90)$ & $0,101^{*}$ \\
\hline -Post & $83,75(67,5-100)$ & $67,5(45-100)$ & $0,022^{*}$ \\
\hline \multicolumn{4}{|l|}{ General health } \\
\hline -Pre & $75(40-80)$ & $55(20-80)$ & $0,226^{*}$ \\
\hline -Post & $80(80-100)$ & $75(55-100)$ & $<0,001^{*}+$ \\
\hline \multicolumn{4}{|l|}{ Vitality } \\
\hline -Pre & $82,5(35-100)$ & $65(45-80)$ & $0,064^{*}$ \\
\hline -Post & $97,5(80-100)$ & $80(70-100)$ & $0,002^{* *}$ \\
\hline \multicolumn{4}{|l|}{ Role emotional } \\
\hline -Pre & $66,7(0-100)$ & $66,7(0-100)$ & $0,432^{*}$ \\
\hline -Post & $100(66,7-100)$ & $66,7(33,3-100)$ & $0,027^{*}$ \\
\hline \multicolumn{4}{|l|}{ Total SF-36 } \\
\hline -Pre & $70,10 \pm 18,94$ & $57,90 \pm 16,84$ & $0,090^{\dagger}$ \\
\hline -Post & $90,53 \pm 8,23$ & $76,98 \pm 11,88$ & $0,002^{\dagger}$ \\
\hline
\end{tabular}

${ }^{*}$ Mann Whitney; ${ }^{\dagger}$ Independent $\mathrm{t} ;{ }^{\ddagger}$ Significant 


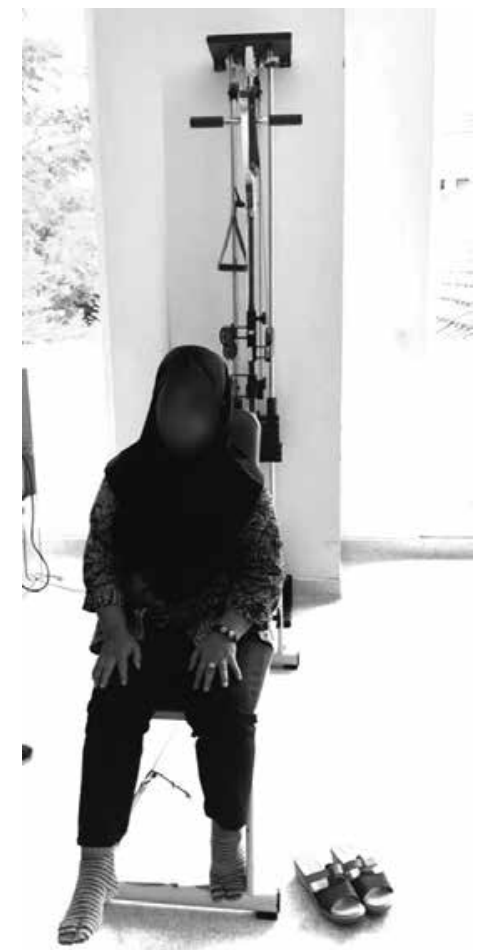

Figure 2. Weight-pulley system exercise

Total score of SF-36 also improved between two groups (table 2). However, from the independent t-test, there was statistically significant difference between intervention and control groups for total

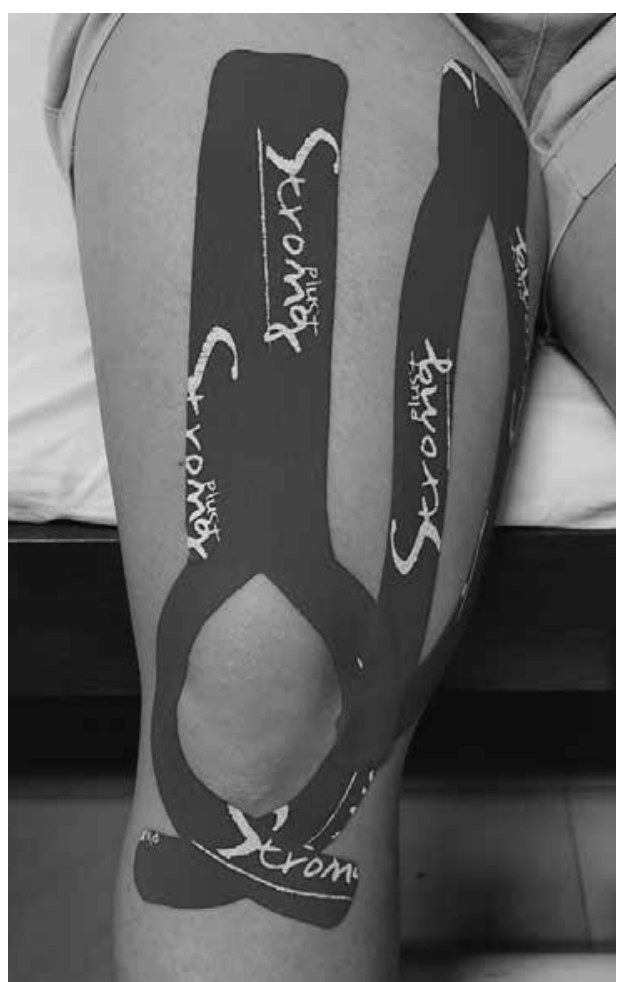

Figure 3. Application of kinesio taping

score of SF-36 at the end of the research with $\mathrm{p}=0.002$ with higher score for intervention group (figure 4).

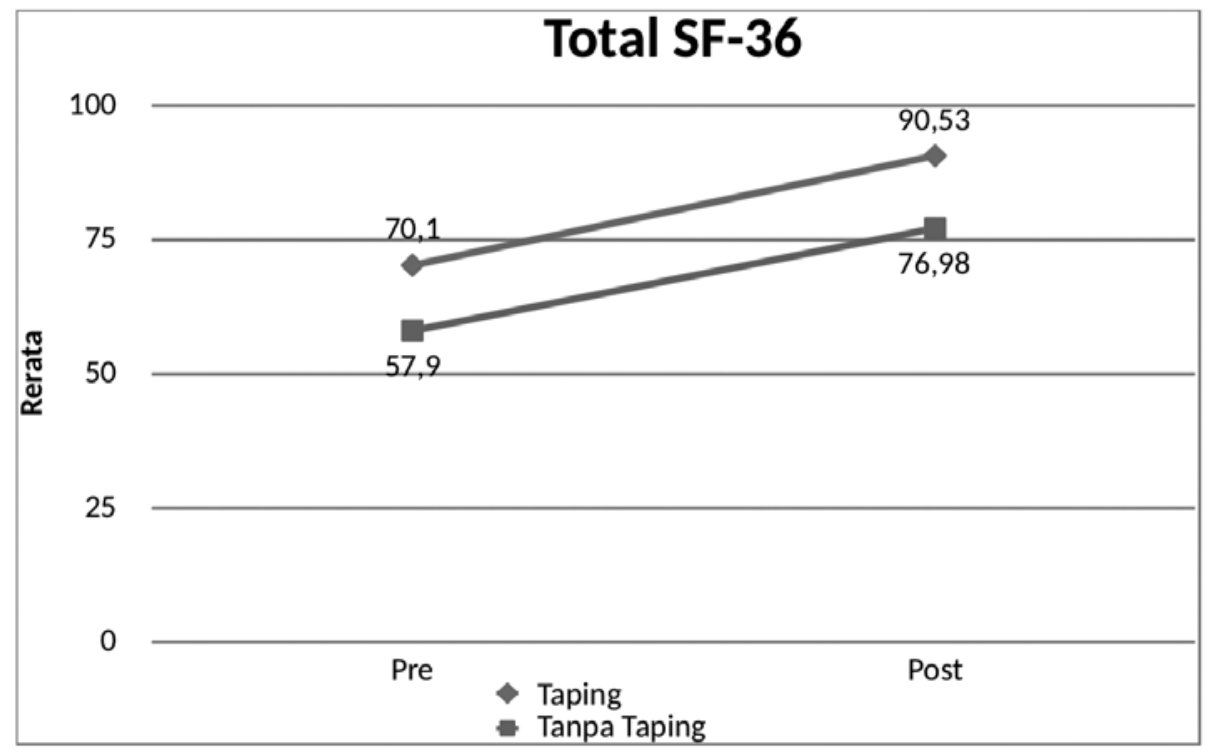

Figure 4. Total SF-36 mean score between intervention and control group. 


\section{DISCUSSION}

In this study, we examined the effect of kinesiotaping in addition to weight pulley system exercise to quality of life of knee OA patients, particularly grade II and III. We measured and compared patients' quality of life using total score and subscales of SF-36. Based on the result of this study, the quality of life was improved in intervention compared to control group (table 2), particularly in total score of SF-36 $(90.53 \pm 8.23, \quad 76.98 \pm 11.88$ respectively, $\mathrm{p}=0.002$ ), subscales of bodily pain $(83.75 \pm 16.86,67.31 \pm 17.39$ respectively, $\mathrm{p}=0.022)$ general health $(88.57 \pm 10.27$, $72.69 \pm 12.18$ respectively, $\mathrm{p}=<0.001)$, vitality $(93.93 \pm 7.64, \quad 80.77 \pm 10.18$ respectively, $\mathrm{p}=0.002)$ and role emotional $(92.86 \pm 14.18$, $74.37 \pm 24.17$ respectively, $\mathrm{p}=0.027$ ).

There was very limited study that directly measured effectiveness of kinesiotaping on quality of life of knee in OA patients. However, our findings were consistent with Hinman et al. that therapeutic taping has proven in increasing the QoL in OA Knee subjects by SF-36 score. ${ }^{21}$ In order to explain the improvement, we required to look further to subscales that were significantly improved with the application of kinesiotaping.

In this study has proven that kinesiotaping combined by sistematic weight pulley exercise significantly improved SF-36 subscales score in terms of bodily pain, general health, vitality and role emotional, as well as the total score of QoL by SF 36 . This evidence in line with Nwe et al. and Aydoğdu et al., that found kinesiotaping increasing healing process of the body by improving blood and lymph flow, decreasing pain and supporting anatomical structure. ${ }^{22,23}$ While, Rahlf et al. has shown the mechanism of kinesiotaping directly influence pain perception. ${ }^{24}$ Donec et al. also supported this study by theory that kinesiotaping can stimulate mechanoreceptors at the skin and increase feedback to the brain resulting in decreased pain. ${ }^{25}$

The most important managements of knee OA, kinesiotaping is proposed to have the ability to strengthen quadriceps femoris muscle as it applied over the muscle. Quadriceps femoris muscle is the main knee extensor muscle, which an important role in maintaining the stability and function of the knee joint. ${ }^{8,23}$ The quadriceps femoris muscle can perform several functions on the knee with isometric, eccentric and concentric activation. Through isometric activation, the quadriceps femoris femoris muscle stabilizes and helps protect the knee joint. ${ }^{23}$ Eccentric activation provides the benefit of "shock absorption" in the knee. The quadriceps femoris muscle helps reduce the impact of loading/impact loading on the knee by functioning as a spring, thus a strong quadriceps femoris muscle can protect knee joint, decrease pain and improve role of the patients. ${ }^{26}$

Park et al explained that kinesio taping may facilitate and immediately increase muscle strength by concentrically pulling the fascia which then stimulate the muscle. ${ }^{27}$ In our research, we also did the facilitation technique by pulling the taping for $40 \%$ over the muscle from origin to insertion of the muscle. Aktas et al. mentioned that kinesio taping with facilitatition technique can increase motor unit recruitment and strengthening the muscle. ${ }^{28}$ Beside that, the position of kinesio taping may give additional support to the knee joint structure and reduce the force. 
The data has revealed from this study, that physical functioning, role physical, mental health and social functioning, were no significant differences between intervention and control group. This might due to the subjects were still active in social function, and cope the pain sensation by physically active.

This study has several limitations including we only did the evaluation post-treatment once after three weeks, thus we cannot examine long term effect of kinesiotaping and we only assessed the quality of life using SF-36.

\section{CONCLUSSION}

Application of kinesiotaping combined with weight-pulley system exercise improved the quality of life in terms of bodily pain, general health, vitality and role emotional in grade II and III knee osteoarthritis patients.

\section{REFERENCE}

1. Newberry SJ, FitzGerald J, SooHoo NF, Booth M, Marks J, Motala A, Apaydin E, Chen C, Raaen L, Shanman R, Shekelle PG. Treatment of Osteoarthritis of the Knee: An Update Review. Comparative Effectiveness Review No. 190. (Prepared by the RAND Southern California Evidence-based Practice Center under Contract No. 290-2015-00010I.) AHRQ Publication No.17-EHC011-EF. Rockville, MD: Agency for Healthcare Research and Quality; May 2017. Available at: www.effectivehealthcare.ahrq.gov/ reports/final.cfm. Accessed on May 10, 2020.
2. Mora JC, Przkora R, Cruz-Almeida Y. Knee osteoarthritis: pathophysiology and current treatment modalities. J Pain Res. 2018;11:2189-2196. doi:10.2147/JPR. S154002

3. Lespasio MJ, Piuzzi NS, Husni ME, Muschler GF, Guarino A, Mont MA. Knee Osteoarthritis: A Primer. Perm J. 2017;21:16183. doi:10.7812/TPP/16-183

4. Ahmad IW, Rahmawati LD, Wardhana TH. Demographic Profile, Clinical and Analysis of Osteoarthritis Patients in Surabaya. Biomolecular and Health Science Journal. 2018;01(01):34-9.

5. Alkan BM, Fidan F, Tosun A, Ardiçoğlu O. Quality of life and self-reported disability in patients with knee osteoarthritis. Mod Rheumatol. 2014;24(1):166-171. doi:10.310 9/14397595.2013.854046

6. Neogi T. The epidemiology and impact of pain in osteoarthritis. Osteoarthritis Cartilage. 2013;21(9):1145-1153. doi:10.1016/j. joca.2013.03.018

7. Slemenda C, Brandt KD, Heilman DK, et al. Quadriceps weakness and osteoarthritis of the knee. Ann Intern Med. 1997;127(2):97-104. doi:10.7326/0003-4819-127-2-19970715000001

8. Alnahdi AH, Zeni JA, Snyder-Mackler L. Muscle impairments in patients with knee osteoarthritis. Sports Health. 2012;4(4):284292. doi:10.1177/1941738112445726

9. Oliveira AM, Peccin MS, Silva KN, Teixeira LE, Trevisani VF. Impact of exercise on the functional capacity and pain of patients with knee osteoarthritis: a randomized clinical trial. Rev Bras Reumatol. 2012;52(6):876-882 
10. Perdosri. Latihan Penguatan Otot. Layanan Kedokteran Fisik dan Rehabilitasi. Jakarta: PB Perdosri; 2013. p. 200-10.

11. Brody LT, Hall CM. Therapeutic Exercise: Moving Toward Function: Wolters Kluwer/ Lippincott Williams \& Wilkins Health; 2011. P. 151-8.

12. Anandkumar S, Sudarshan S, Nagpal P. Efficacy of kinesio taping on isokinetic quadriceps torque in knee osteoarthritis: a double blinded randomized controlled study. Physiother Theory Pract. 2014;30(6):375-383. doi:10.3109/09593985 . 2014.896963

13. Perdosri. Prosedur Taping. In: Wirawan RP, Wahyuni LK, Hamzah Z, editors. Asesmen dan Prosedur Kedokteran Fisik dan Rehabilitasi. Jakarta: PB Perdosri; 2012. p. 168-71.

14. Kase K. Illustrated Kinesio Taping. Tokyo: Ken'i Kai; 2005. p. 92-3

15. Karamitabar A., Shahali S., Dadgoo M., Mansour Sohani S., Ghorbanpour A., Abrisham Karzadeh H., Jaafari H., Mirbehresi P. The Effect of Kinesio Tape on Knee Pain and Quality of Life in Subjects with Knee Osteoarthritis - A Randomized clinical Trial. Function and Disability Journal. 2019 (Winter). Vol: 1.No: 4 Pages: 27-36. doi: 10.30699/fdisj.1.4.27

16. Lu Z, Li X, Chen R, Guo C. Kinesio taping improves pain and function in patients with knee osteoarthritis: A metaanalysis of randomized controlled trials. Int J Surg. 2018;59:27-35. doi:10.1016/j. ijsu.2018.09.015
17. Kaya Mutlu E, Mustafaoglu R, Birinci T, Razak Ozdincler A. Does Kinesio Taping of the Knee Improve Pain and Functionality in Patients with Knee Osteoarthritis?: A Randomized Controlled Clinical Trial. Am J Phys Med Rehabil. 2017;96(1):25-33. doi:10.1097/PHM.0000000000000520

18. Lins L, Carvalho FM. SF-36 total score as a single measure of health-related quality of life: Scoping review. SAGE Open Med. 2016;4:112. doi.org/10.1177/2050312116671725

19. Kawano MM, Araújo ILA, Castro MC, Matos MA. Assessment of quality of life in patients with knee osteoarthritis. Acta Ortop Bras. [online]. 2015;23(6):307-10. Kawano MM, Araújo IL, Castro MC, Matos MA. Assessment of quality of life in patients with knee osteoarthritis. Acta Ortop Bras. 2015;23(6):307-310. doi:10.1590/1413785220152306150596

20. Bennell KL, Hinman RS. A review of the clinical evidence for exercise in osteoarthritis of the hip and knee. $J$ Sci Med Sport. 2011;14(1):4-9. doi:10.1016/j. jsams.2010.08.002

21. Hinman RS, Crossley KM, McConnell J, Bennell KL. Efficacy of knee tape in the management of osteoarthritis of the knee: blinded randomised controlled trial. BMJ. 2003;327(7407):135. doi:10.1136/ bmj.327.7407.135

22. Nwe, A., Tun, M., Aung, S., Tun, L., \& Myaing, K. (2019). Effectiveness of Kinesio Taping in the Management of Knee Osteoarthritis. Journal of Advances in Medicine and Medical Research, 29(2), 1-10. doi:10.9734/jammr/2019/v29i230063 
23. Aydoğdu O, Sari Z, Yurdalan SU, Polat MG. Clinical outcomes of kinesio taping applied in patients with knee osteoarthritis: A randomized controlled trial. $J$ Back Musculoskelet Rehabil. 2017;30(5):10451051. doi:10.3233/BMR-169622

24. Rahlf AL, Braumann KM, Zech A. Kinesio Taping Improves Perceptions of Pain and Function of Patients With Knee Osteoarthritis: A Randomized, Controlled Trial. J Sport Rehabil. 2019;28(5):481-487. doi:10.1123/ jsr.2017-0306

25. Donec V, Kubilius R. The effectiveness of Kinesio Taping ${ }^{\circledR}$ for pain management in knee osteoarthritis: a randomized, double-blind, controlledclinicaltrial.TherAdvMusculoskelet Dis. 2019;11:1759720X19869135. doi:10.1177/1759720X19869135
26. Imoto AM, Peccin MS, Trevisani VF. Quadriceps strengthening exercises are effective in improving pain, function and quality of life in patients with osteoarthritis of the knee. Acta Ortop Bras. 2012;20(3):174-179. doi:10.1590/S141378522012000300008

27. Park JS, Yoon T, Lee $\mathrm{SH}$, et al. Immediate effects of kinesiology tape on the pain and gait function in older adults with knee osteoarthritis. Medicine (Baltimore). 2019;98(45):e17880. doi:10.1097/ MD.0000000000017880

28. Aktas G, Baltaci G. Does kinesiotaping increase knee muscles strength and functional performance? Isokinet Exerc Sci. 2011;19(3):149-55. doi: 10.3233/IES-20110408. 